\title{
Investigating neoclassicism around Alexandre Tansman
}

\author{
Luigi Brandão
}

\author{
Universidade do Estado de Santa Catarina | Brasil
}

\begin{abstract}
Resumo: Conduz-se uma investigação sobre a questão do neoclassicismo ao redor da figura pública de Alexandre Tansman. O objetivo é traçar um mapa de algumas das maneiras pelas quais o compositor é ligado ao neoclassicismo. Partindo de consideraçôes sobre o termo neoclassicismo, faz-se uma análise sobre como comentadores veem a relação de Tansman com o termo, tanto no que tange suas ideias sobre música e arte quanto no que tange suas escolhas e procedimentos composicionais. Em seguida, uma seção dedicada à questão do neoclassicismo na obra para violão de Tansman apresenta um argumento contra o emprego fácil do termo dentro deste repertório. A seção final resume a discussão e apresenta uma representação gráfica dos resultados desta investigação.
\end{abstract}

Palavras-chave: Alexandre Tansman, Neoclassicismo, Biografia Musical.

\begin{abstract}
In this essay, I investigate the issue of neoclassicism around the public figure of the polish composer Alexandre Tansman. The objective is to chart some of the ways in which the composer is related to neoclassicism. I begin by presenting an understanding of the term neoclassicism and proceed to an investigation of how commentators see Tansman's relation to it, both in relation to his ideas on music and art and in relation to compositional decisions and procedures. Toward the end of the essay, a section is dedicated to the issue of neoclassicism in Tansman's guitar works, in which I present an argument against the easy use of the term within this repertoire. The final section wraps up the discussion and presents a graphical representation of the results of the present investigation.
\end{abstract}

Keywords: Alexandre Tansman, Neoclassicism, Musical Biography. 
I

$\mathrm{n}$ recent assessments of musical biography and its relation to musicology, ${ }^{1}$ scholars have argued for a more contextual understanding of the accounts and descriptions surrounding public

figures in the musical world, focused on understanding why stories are told in the way they are told, what is the cultural significance of recurring narratives surrounding a certain figure, and how these narratives relate to a broader social and cultural context in the process of building this compound of facts and interpretations which we perceive as the life stories of notable musicians.

In this paper, I attempt to proceed in such a way in investigating the relation between the polish musician Alexandre Tansman (1897-1986) and notions of neoclassicism. I will try to chart different ways in which Tansman is connected to this movement which, for the purpose of this paper, is perceived as an artistic movement that gained strength in Europe between the two World Wars. In doing so, I will discuss the ways in which the composer perceived tradition and neoclassicism, the ways in which people who connect Tansman to the neoclassical movement do so, the musicians who were close to the composer and were likewise tied to the neoclassical movement, and the use of the term neoclassical in relation to Tansman's guitar works.

Though I will discuss some of the composer's works throughout the text, the goal here is not to identify within his works aspects that can be perceived as neoclassical, but rather to present an overview of some of the ways by which the composer is tied to such movement, in the hopes that this effort of contextualization may be of assistance in the investigation of neoclassical traits in Tansman's music. For a more analytical investigation of neoclassicism in one of the composer's works, please refer to my master's dissertation Entrelinhas: Alexandre Tansman e as Variations sur un thème de Scriabine (2020).

\section{Encircling neoclassicism}

In order to explore this relation between Tansman and neoclassicism, it is necessary to define what is to be understood as neoclassicism within the scope of this research. As is noted by many authors who face the task of defining neoclassicism, such a term may not only be used in a vague way which seems to presume the existence of a tacit understanding of its meaning between writer and

1 See Pekacz (2004) and Wiley (2008; 2010). 
reader, but also the term itself may come to have different meanings depending on what the people employing it conceive as "neoclassical".

To extend the argument a bit further, let me cite how Martha Hyde invites the reader to reflect upon the issue at hand in a very simple, albeit not simplistic, approach: In asking oneself "what makes something neoclassical?", one must also satisfyingly account for the question "what is a classic?". Already at this point we see that one may come to profoundly different answers to the first question, given that the second one can also be answered in different ways, according to different parameters. To Hyde (1996, p. 201), "a classic is a past work that remains or becomes relevant and available as a model". Thus, within this framework, a classic is defined in a way that is completely detached from specific period styles or time frames; a work becomes a classic by the ways in which it is used throughout time. One can, therefore, imagine a very unspecific type of neoclassicism on what concerns the final stylistic aspects of the works in themselves, for one may find "works which have become or remained relevant and available as models" both within music from the $18^{\text {th }}$ and $19^{\text {th }}$ centuries as well as without its limits.

Indeed, to Hyde, one of the most important aspects of neoclassical aesthetics - what she calls metamorphic anachronism - has to do with how one approaches the models: troubled by the need to represent the past in their works without sacrificing their personal integrity as composers, musicians from the beginning of the $20^{\text {th }}$ century who had some affinity with the idea of neoclassicism sought ways in which they could relate the present to a specific past while at the same time dramatizing the passage of time between them. It is from this perspective that I will discuss neoclassicism in this essay. This is important because, further along, it is from this perspective that I will question the meaning and applicability of the term within the scope of Tansman's works for guitar.

This notion of what makes a classic is very close to what Granat-Janki understands as Tansman's take on the subject (GRANAT-JANKI, 2001, on-line):

For the composer, "classicism" was not only a definite historical period but it was also synonymous with excellence, perfection and universal recognition. He believed that ideally - all art should be based on classical aesthetics, developing from the principles of harmony, moderation, and order. While asserting the predominance of the classical traits of clarity and harmony, Tansman was convinced that in every historical period, art - and especially music - included patterns that could be acknowledged as "classical" for their time; therefore, "classical" patterns may be found in each historical epoch 
One should also consider the neoclassical movement from a geographical and historical point of view since these aspects play an important role in Tansman's relation to it. Though Messing (1991, p. 482-491) traces a long history of the term and its different meanings before it came to be understood as such, I shall hereby discuss the neoclassical movement as something which took place in Europe between 1920 and 1930, and which some authors ${ }^{2}$ tie more or less specifically to France.

\section{Associations between Tansman and neoclassicism}

In considering the relation between Tansman and Neoclassicism, I should first and foremost state that I have not found any letter, interview or paper in which Tansman presents himself as a neoclassical composer. The associations between the composer and neoclassicism that I have come upon were all produced by other people, in texts either of biographical or critical nature. This is apparently also the case with other musicians who were close to Tansman and who are occasionally described as neoclassical, such as Ravel and Stravinsky. In fact, one of the people who described Stravinsky as neoclassical was Tansman himself, in a text originally published in 1966:

Between the two [world] wars, the most significant currents in contemporary music were crystallized around two main poles, briefly defined as neoclassicism and expressionism, and respectively represented by Igor Stravinsky and the Viennese School of Arnold Schoenberg, Alban Berg and Anton von Webern. A third force, denominated "folk", is expressed in the multiple genius of Bela Bartok, whose work surpasses by far this limited definition of "folk music”. As schematic and arbitrary as it may seem, this somewhat restrict and artificial distinction presents nevertheless the advantage of being based on notions of aesthetic order (whereby even the use of means of expression is determined by a discipline, an objective or subjective attitude by the creator in relation to his art, the role of the "personal ego"), and not only by manifestations of a purely technical order (its notation, an extreme exteriorization bordering exhibitionism)" (TANSMAN, 2005, p. 61, translated by the author $)^{3}$

\footnotetext{
${ }^{2}$ See Messing (1991), Dinkel (1984).

3 "Entre les deux guerres, les courants les plus significatifs de la musique contemporaine se sont cristallisés autour de deux pôles principaux, définis sommairement néoclassicisme et expressionnisme, et représentés respectivement par Igor Stravinsky et l'École de Vienne d'Arnold Schoenberg, Alban Berg et Anton von Webern. Une troisième force, dénommée « folklorique », s'est exprimée dans le génie multiple de Bela Bartok dont l'œuvre surpassait de loin cette définition limitée de «folklore ». Aussi schématique et arbitraire que puisse parâtre cette classification, quelque peu restreinte et artificielle, elle présente néanmoins l'avantage d'être basée sur des notions d'ordre esthétique (où même l'utilisation des moyens d'expression a été déterminée par une discipline, une attitude objective ou subjective du créateur vis-à-vis de son art, le rôle de 1'« ego personnel»), et non uniquement par des manifestations d'ordre purement technique (son écriture, son graphisme, une extériorisation à outrance allant jusqu'à l'exhibitionnisme)" (TANSMAN, 2005d, p. 61).
} 
Béla Bartók makes a very similar categorization of early $20^{\text {th }}$-century music which is quoted in a paper by Bónis (1983, p. 73-74). The relation between Stravinsky and Tansman seems to have been very important to the latter, ${ }^{4}$ who wrote a book about the Russian composer. This relationship, as well as the fact that Tansman resided in France during the interwar period, are all elements which Granat-Janki (2001, on-line) refers to when describing the composer's relation to the neoclassical movement. Let me first quote Granat-Janki as she associates Tansman's relationship with France as one of the reasons for his involvement with neoclassicism: "Tansman spent most of his creative life in Paris [...], married a French pianist and became a French citizen in 1938. The strong impact of neoclassicism on his compositional style reveals this French connection”.

The author also writes that "in Paris he became involved in creative activities, which resulted in the formation of a new trend in the music of the 20th-century - neo-classicism. Besides Stravinsky and French composers from 'The Group of Six,' Tansman was one of the co-creators of a new 'classical' orientation in French music in the 1920s". ${ }^{5}$ In this quote, the author evokes the association between Tansman, Stravinsky, and Le groupe des Six, ${ }^{6}$ and portrays the polish composer as an active participant in the establishment of a renewed "classical" orientation within French music. This brings to mind the historical unfolding of the term nouveau classicisme, ${ }^{7}$ a term which would end up as a synonym of neoclassicism and which shared with the latter many of the renewed "classical values" such as clarity, order and balance. ${ }^{8}$

These values are evoked by Timmons and Frémaux in describing the compositional practice of the polish composer; the authors write that Tansman "always strove to achieve a balance in the musical measures and to sharply define the plan of the structure" (TIMMONS; FRÉMAUX, 1998, emphasis mine). These authors also tie Tansman to the neoclassical movement within the specific

\footnotetext{
${ }^{4}$ See Timmons and Frémaux (1998), Hugon (1998; 2005) and Otero (2011) for some accounts of the relation between Tansman and Stravinsky. Also, evidently, see Tansman's book Igor Stravinsky: the man and his music (1949) or the book Une voie lyrique dans un siècle bouleversé (2005), where one may find some excerpts of the former.

${ }^{5}$ Another composer who seems to have been important to Tansman, and whose works are sometimes discussed vis-à-vis neoclassicism (as is the case in Hyde's paper) is Maurice Ravel. In an interview transcribed in Timmons and Frémaux (1998), Tansman states that Ravel was "a kind of father to him" and played an important part in introducing the polish composer to Parisian musical circles.

${ }^{6}$ For an investigation on how the French neoclassical movement and Le groupe des Six are related to Claude Debussy and “anti-Debussysm”, see Wheeldon (2017).

${ }^{7}$ Though it may not seem so, in an earlier period of French critical thought on music the terms nouveau classicisme and neoclassicisme meant very different things. For a detailed account, see Messing (1991, p. 483).

${ }^{8}$ See Whittall (2001), Solomos (1998, p. 92), Dinkel (1984), Messing (1991, p. 489).
} 
timeframe I have mentioned before, asserting that "European neo-classicism of the twenties and thirties was the framework in which Tansman's creative effort developed” (TIMMONS; FRÉMAUX, 1998, on-line). Later in the same paper, the authors state that the composer had "an almost religious enthusiasm for neo-classicism", though they cite no works in which such enthusiasm may be perceived.

When commenting the composer's views on tradition, ${ }^{9}$ Granat-Janki presents an argument which, in a way, complexifies the perception of the composer as neoclassical:

\begin{abstract}
One of the most significant features of neoclassicism was its "historicism" which manifested itself in the links with music traditions of different periods. Tansman's music reveals a strong awareness of the ties with tradition to a similar extent as it could be noticed in the works composed by Igor Stravinsky, Darius Milhaud or Arthur Honegger. Tansman recognized the importance of tradition, for instance in the following statement: "Tradition is like a tree: dry branches fall down, but uprooting the tree is dangerous, the roots must remain". The composer thought that it was impossible to break away from musical tradition, and that there was no such need. He believed that "the dry branches" of ossified traditionalism fall down spontaneously, and therefore tradition undergoes constant renewal, "permanent enrichment". (GRANAT-JANKI, 2001, on-line).
\end{abstract}

By evoking tradition as a tree from which dry branches fall on their own, ${ }^{10}$ the composer helps us understand his relation with the musical legacy of the past, as well as the fact that he is sometimes associated both with the neoclassical movement and with the romantic legacy. ${ }^{11}$ Because Tansman believes that what comes from tradition and is no longer of use to contemporary composers naturally falls into disuse, he may have been able to look at the romantic legacy, recognize in it that of which he did not wish to partake, ${ }^{12}$ and use it as one of his sources for models, without necessarily contradicting the general ideas of the neoclassical movement. It cannot go unnoticed, however, that what is being hereby described is akin to what Dinkel (1984), after the Swiss-German musicologist Hermann Danuser, describes as historicism, and that the author states that this would be different from "proper neoclassicism”, the latter having as an essential aspect the negation of the romantic legacy and its

\footnotetext{
${ }^{9}$ For some of the composer's comments on tradition in music, see Brandão and Holler (2019a).

${ }^{10}$ An image which alludes to the notion of organicism, which was itself highly valued in Romanticism. See Montgomery (1992) and Levy (1987).

${ }^{11}$ See Rae (2001), Granat-Janki (2001).

12 "Being with Stravinsky helped me consider music for its own sake, as an autonomous and absolute art form, and recover

a traditional aesthetics which had been overshadowed by neo-romanticism and expressionism" (TANSMAN apud TIMMONS; FRÉMAUX, 1998).
} 
values.

To Granat-Janki (2001, on-line), neoclassical traits in Tansman's music are strongly tied to formal aspects. In discussing how the composer makes use of the music from earlier periods in his works, the author writes that "in his large-scale designs Tansman used ideas borrowed from the music of the Baroque, for instance the structural principle of the concerto grosso [...] Another manifestation of Tansman's interest in Baroque music is his use of the form of the suite". In another passage, discussing the relation between Tansman and the classical tradition, the author writes that

\begin{abstract}
Classicism revealed itself in Tansman's oeuvre by means of genres and forms, techniques and types of expression characteristic for the end of the 17th century and the beginning of the 18th century. The composer displayed a marked preference for the genres of the sonata, quartet (and other genres of chamber music), symphony, concerto, rondo, and variations. He often used classical and Baroque architectonic patterns (GRANAT-JANKI, 2001, online).
\end{abstract}

Some other points touched upon by the author are Tansman's use of baroque techniques in his approach to rhythm, and the resemblance of his instrumental textures to those of the classical period.

The reader will remember that, to Martha Hyde, one of the aspects of a neoclassical approach to composition is the deliberate effort of making the historical distance between the model and the new work explicit somehow, or, in a better choice of words, to dramatize it, so that this very effort to merge the past into the present - instead of merely presenting the past in a contemporary composition - becomes a constituent part of the compositional act. In their descriptions of Tansman's compositional practice, Gérald Hugon and Granat-Janki seem to agree that he was a man of his time, that he employed means of expression that were being developed around him, ${ }^{13}$ and that when using materials from the past or taking compositions from the past as models, he did not simply copy them, but rather infused in them novel techniques, harmonies, etc. What is conflictive between these two authors is that this contemporaneous quality is interpreted in different ways on what regards Tansman's relation to neoclassicism: on one hand, Hugon believes the "modern" aspects of

\footnotetext{
${ }^{13}$ Some biographical accounts even suggest he figured how to compose in such means without even being aware that other composers were doing so. I have briefly discussed recurrent narratives on biographical accounts of Tansman, and identified this as one of them, in a critical review of Marianne Tansman's La guitare dans la vie d'Alexandre Tansman. See Brandão and Holler (2019b).
} 
his compositional practice contradict the definition of the composer as neoclassical, as one reads in the following paragraph:

The concept of neoclassicism is not satisfactory in trying to describe Tansman's musical personality; not in the interwar period, and especially not after World War II. Indeed, Tansman's work has its cut of modernity, which resides in certain aspects of his craft and writing: the use of dissonance, an enlarged conception of tonality, a pronounced taste for carefully combined sonorities, a propension toward linear writing, a free conception of form. In addition, he always opposed the "retours $\grave{a}$ ", in essence impossible. Besides, he thought that the music he wrote expressed the sensibility of a man of his time (HUGON, 2005 , p. 47 , translated by the author). ${ }^{14}$

Apparently, what Hugon conceives as neoclassicism is somewhat different from what has been discussed so far; Whittall (2001, on-line), in describing the compositional practice of neoclassical composers, argues precisely that such composers are more likely to present an enlarged or unorthodox approach to tonality rather than reproduce "the hierarchically structured tonal system of true (Viennese) Classicism”. In the same sense, new approaches to composition within old forms are to be expected in a movement which is attempting to present a novel take on past legacies. On what concerns "a propension toward linear writing", one reads in Messing (1991, p. 489) that polyphony, counterpoint and linear writing are all notions which were valued - and, if I may add, used as descriptive attributes of musical value - in the context of neoclassicism. Nevertheless, Hugon's emphasis on denying associations between Tansman and neoclassicism after World War II is worth being considered within the definition I have made of the neoclassical movement at the beginning of this paper - that is, a movement which had its strongest expression in Europe somewhere between the two World Wars. It is also something I will come back to later on, when discussing the composer's guitar works.

Granat-Janki, on the other hand, seems to understand that the modern aspects of Tansman's music do not contradict or compromise his relation to the music of the past nor that between the composer and the neoclassical movement. She indicates furthermore that this tendency to fuse the

\footnotetext{
14 “'Le concept de néoclassicisme n'est pas satisfaisant pour tenter de décrire la personnalité musicale de Tansman, ni dans l'entre-deux guerres, ni surtout après la Seconde Guerre mondiale. En effet, l'œuvre de Tansman comprend sa part de modernité qui réside dans certains aspects de l'écriture et de la facture : l'emploi de la dissonance, une conception tonale élargie, un goût prononcé pour les sonorités soigneusement combinées, une propension à l'écriture linéaire, une conception libre de la forme. En outre, il s'est toujours opposé aux 'retours à', par essence impossibles. Il estimait en outre que la musique qu'il écrivait, exprimait la sensibilité d'un homme de son temps” (HUGON, 2005, p. 47).
} 
ancient and the contemporary, which is hereby understood as one of the central aspects of neoclassicism, has remained with the composer long after the timeframe in which I have encompassed the neoclassical movement:

While referring to the past in his music, Tansman did not slavishly copy the patterns adopted from the previous epochs. Instead, he reinterpreted the tradition through modern means of his compositional technique. In the Poetics of Music Igor Stravinsky stated: 'You refer to tradition in order to create something new.' Aleksander Tansman understood the return to the musical heritage of other generations in the same way. The references to the legacy of the past became a characteristic feature of his style not only in the years 19201941, when the composer's musical language was developed but also in the mature period of his creative activity - after the year 1941 (GRANAT-JANKI, 2001, on-line).

In her paper, the author cites some of the composer's works while describing his relation to neoclassicism and to the baroque and classical heritages. These works are listed in CHART 1 with a brief description of the context in which they are presented.

CHART 1 - Works cited by Granat-Janki when defining Tansman's relation to neoclassicism and to the classical and baroque legacies in her paper Tradition and Modernity in the music of Aleksander Tansman (2001)

\begin{tabular}{|c|c|c|c|}
\hline Work & Excerpt & Context & $\begin{array}{c}\text { Year of } \\
\text { composition }\end{array}$ \\
\hline $\begin{array}{l}\text { Piano Concerto } \\
\text { no. } 2,1 \text { st } \\
\text { movement, } 2^{\text {nd }} \\
\text { theme }\end{array}$ & $\begin{array}{l}\text { mm. } \mathbf{4 1 - 4 3} \text { - a melody roughly } \\
\text { around A minor is played above an } \\
\text { accompaniment which alternates } \\
\text { between A minor and a D chord with } \\
\text { the } 9^{\text {th }} \text { instead of the } 3^{\text {rd, }} \text { forming two } \\
\text { independent layers in terms of rules of } \\
\text { counterpoint and voice leading. }\end{array}$ & $\begin{array}{l}\text { Relation to the classical tradition } \\
\text { - use of homophonic texture }\end{array}$ & 1927 \\
\hline $\begin{array}{c}\text { Symphonie no. } 2 \\
\text { in A minor, } 3^{\text {rd }} \\
\text { movement, } \\
\text { Scherzo }\end{array}$ & $\begin{array}{l}\text { mm. 1-3 - a motoric pattern of } \\
\text { minor seconds is shared among some } \\
\text { of the instruments }\end{array}$ & $\begin{array}{l}\text { The use of motor-like rhythmic } \\
\text { patterns as an inheritance from } \\
\text { the baroque legacy. }\end{array}$ & 1926 \\
\hline $\begin{array}{c}\text { Piano Concerto } \\
\text { no. } 2,3^{\text {rd }} \\
\text { movement, Finale }\end{array}$ & $\begin{array}{l}\text { Superposition of themes between the } \\
\text { piano and the wind section }\end{array}$ & $\begin{array}{c}\text { The use of polyphonic techniques } \\
\text { as an aspect of Tansman's } \\
\text { neoclassical orientation }\end{array}$ & 1927 \\
\hline $\begin{array}{l}\text { Concerto for } \\
\text { Orchestra }\end{array}$ & -- & $\begin{array}{l}\text { "Typical neoclassical traits may be } \\
\text { found, for instance, in the } 1954 \\
\text { Concerto for Orchestra, a work } \\
\text { which is the most mature from } \\
\text { the point of view of Tansman's } \\
\text { individual style" (GRANAT- } \\
\text { JANKI, 2001, on-line). }\end{array}$ & 1954 \\
\hline
\end{tabular}

Source: Compiled by the author. 


\section{Neoclassicism and Tansman's guitar works}

The last topic I intend to approach in this paper are Tansman's guitar works. In order to understand the relationship between this section of the composer's work and the term neoclassicism, one must consider the fact that these works were almost entirely commissioned by Andrés Segovia, and examine the details of the relationship between Tansman and the Spanish guitarist.

The relationship between the two musicians began sometime around 1925, when Tansman attended a performance by Segovia in France; from this initial meeting came forth a Mazurka, the first of many compositions Tansman would write to the guitarist. Commentators of this part of Tansman's oeuvre recurrently mention Segovia's stylistic preferences as something which would have a crucial influence on the composer's output. Marianne Tansman and Fréderic Zigante cite letters exchanged between Segovia and Tansman in which the former makes very specific requests regarding the style and overall characteristics of the pieces being commissioned. Marianne Tansman (2018, p. 36), musing on the possible reason for delays in the interpretation of specific works, alludes to Segovia's romantic taste and refusal of atonality, and Zigante (2003) quotes letters in which Segovia praises and beckons Tansman's classical discipline and clarity of writing in the commission of new works, sometimes asking for a "not too dissonant writing".

Zigante also states that as their relationship would progress, Tansman would better understand his client's preferences and requests, especially after 1960 . According to the author (2003, p. 15), the impact Segovia had on the works he decided to take to the stage or to the recording studio was so strong that he became a kind of co-author of the works. This is a very notable quote if one takes into account the fact that, back when both musicians were alive, Segovia was practically the only person responsible for the editing of Tansman's guitar works, and that he only took to the final stages of the editing process those works which he did indeed play or record. In practical terms, this means that not only most people get to know but a fraction of Tansman's guitar works, but also that they get to know a collection of works of which the compositional process was carefully and closely supervised by Segovia, and thus may well have a very different character from the works which the guitarist did not edit or actively participate in the composition process. It is in light of these considerations that Zigante hints at the argument which I wish to develop, by writing that Tansman's compositions for guitar were "always soaked with that kind of neoclassicism which is quite rare among the remainder of his work” (ZIGANTE, 2003, p. 15). 
It is against this backdrop that one should reconsider the use of the term neoclassic in relation to Tansman's guitar works, by taking into account the demands of Andrés Segovia for a music which refrained from modern styles and often alluded to earlier periods, and also that the few compositions which were effectively recorded or taken to the stage underwent sometimes intense editing between Tansman and Segovia.

Let me furthermore point out that most of these works were written after "the height" of the neoclassical movement, since Tansman's second guitar work would only be written in 1950. Let us remember as well Zigante's remark that the composer's guitar works displayed a kind of neoclassicism which was very different from what one may hear in the rest of his works. It is from this point of reference that I would like to advance the argument that Tansman's guitar works may not necessarily be neoclassical, but something else: a different effort of creative re-presentation of stylistic and formal aspects of the music of earlier periods, an effort which is not necessarily concerned with the deliberate dramatization of the passage of time between its models and the resulting compositions, and therefore produces works which are not necessarily neoclassical in the sense of the term I have been discussing so far.

I would thus call into question the use of the term neoclassical in describing Tansman's guitar music, and would suggest thorough research involving the formal and stylistic aspects, as well as attempts to determine if, and how, the historical distance between the compositional models and the composition itself is made evident by the composer, before attributing the title of "neoclassical" to any of these works. I myself have tried to do so elsewhere with the Variations sur un thème de Scriabine, ${ }^{15}$ and have precisely come to the conclusion that this work in particular does not benefit from, or stands well against, a neoclassical interpretation. Again, this is not to say that none of Tansman's works for guitar may be called neoclassical, but that historical evidence suggests they are something else.

To sum it up, why would the easy use of the label neoclassical, in this context, be a problem? Why, it may well be the case that if we look at these works expecting to see something neoclassical in them, we may only be frustrated in our efforts of finding something which is simply not there to be found. Or we may end up stretching the concept of neoclassicism in order to encompass works which we presume to be neoclassical, and in doing so (1) we further weaken an already stigmatized term,

\footnotetext{
${ }^{15}$ See my master's dissertation, Entrelinhas: Alexandre Tansman e as Variations sur un thème de Scriabine (2020).
} 
which despite its poor reputation nowadays is a term that, as Messing (1991) states, plays an important part in the understanding of the music of the first quarter of the $20^{\text {th }}$ century, and (2) we may also do a disservice to Tansman's guitar music, by presenting it as something which it is not, when we could instead look for different terms and ways of describing - and therefore perceiving and valuing - these works, terms from which they could benefit, against which they could stand on their own.

\section{Concluding remarks}

In this research, I have tried to chart ways in which Tansman is related to neoclassicism by his commentators. A basic outline of what has been discussed so far is presented in FIGURE 1; taking into account the argument I presented on what concerns Tansman's guitar music and his relationship with Segovia, I have chosen not to portray it as one of the links, though I acknowledge that, from a different perspective, it might have been considered as an additional connection. As I mentioned in the initial paragraphs, this essay was not concerned with the identification of neoclassical traits in Tansman's music, but rather with how the composer is presented in relation to the neoclassical movement. Hopefully, the issues hereby discussed may serve as contextual support for works which seek to investigate Tansman's music vis-à-vis neoclassicism.

FIGURE 1 - Schematic map of elements through which the relation between Tansman and the neoclassical movement is portrayed.

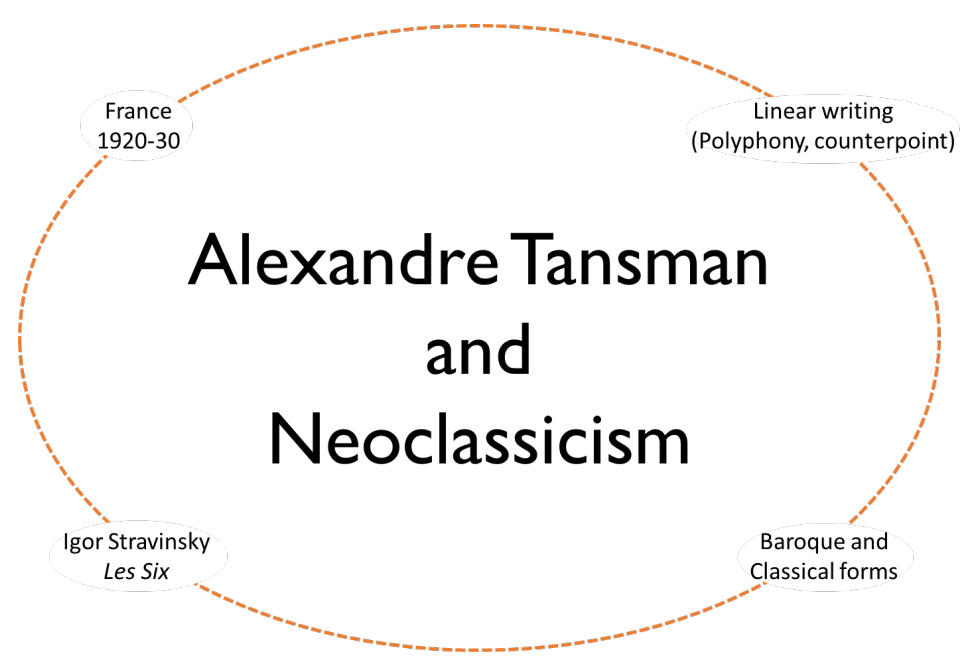

Source: created by the author. 


\section{ACKNOWLEDGMENT}

The investigation on which this essay was based has been conducted under the supervision of Professor Marcos Holler. Some of the arguments I present here have been constructed in conversation with my guitar teacher, Professor Bruno Madeira, and for that I would like to thank him. In general, the ideas I have hereby presented are part of my master's dissertation (BRANDÃO, 2020), and their development has been funded by CAPES - Coordenação de Aperfeiçoamento de Pessoal de Nível Superior -Brasil (CAPES) - Código de Financiamento 001. In these very sensible times for public higher education in Brazil, when it finds itself under a veritable barrage in the form of funding cuts, subjection to capitalist modes of "operation" (CHAUÍ, 1999), and a forceful implementation of remote learning practices, I would like to thank my supervisor, CAPES and the Music Graduate Program of the UDESC Music Department for having provided the tools and opportunities that allowed me to experience education and research in a broad, free and emancipating manner in the past two years.

\section{REFERENCES}

BÓNIS, F. Zoltán Kodály, a Hungarian Master of Neoclassicism. Studia Musicologica Academiae Scientiarum Hungaricae, v. 25, n. 1, p. 73-91, 1983.

BRANDÃO, L.; HOLLER, M. Reflexões sobre escritos de Alexandre Tansman a respeito de tradição em música. Anais do XXIX Congresso da ANPPOM. Pelotas, 2019a.

BRANDÃO, L.; HOLLER, M. Marianne Tansman’s “La guitare dans la vie d'Alexandre Tansman” (2018). Revista Vórtex, v. 7, n. 3, 2019b.

BRANDÃO, L. G. Entrelinhas: Alexandre Tansman e as Variations sur un thème de Scriabine. Dissertação (Mestrado em Música) - Centro de Artes, Universidade do Estado de Santa Catarina. Florianópolis, p. 292. 2020.

CHAUÍ, M. A universidade operacional. Folha de São Paulo, v. 9, n. 5, 1999.

DINKEL, P. Quelques aspects de l'émergence du néoclassicisme au XXe siècle. In: ALBÈRA, P. Avant-garde et tradition: Revue Contrechamps no 3. En ligne. ed. Genève: Éditions Contrechamps, 1984. Available at: <https://books.openedition.org/contrechamps/1177?lang=fr>. Acessed on: January $29^{\text {th }}, 2020$.

GRANAT-JANKI, A. Tradition and Modernity in the Music of Aleksander Tansman. Polish Music Journal, v. 4, n. 1, 2001. 
HUGON, G. Alexandre Tansman. Musica et Memoria, 1998. Available at: $<$ http://www.musimem.com/tansman.htm>. Accessed on: August 14th, 2018.

HUGON, G. Alexandre Tansman: origines et trajectoire d'un accomplissement artistique. In: HUGON, G.; TANSMAN-ZANUTTINI, M. Une voie lyrique dans un siècle bouleversé. Paris: L'Harmattan, 2005. p. 7-50.

HYDE, M. M. Neoclassic and Anachronistic Impulses in Twentieth-Century Music. Music Theory Spectrum, v. 18, n. 2, p. 200-235, 1996.

LEVY, J. M. Covert and Casual Values in Recent Writings about Music. The Journal of Musicology v. 5, n. 1, p. 3-27, 1987.

MARIANNE TANSMAN. La guitare dans la vie d'Alexandre Tansman. France: Editions Habanera, 2018.

MESSING, S. Polemic as History: The Case of Neoclassicism. The Journal of Musicology, v. 9, n. 4, p. 481-497, 1991.

MONTGOMERY, D. L. The Myth of Organicism: From Bad Science to Great Art. The Musical Quarterly, v. 76, n. 1, p. 17-66, 1992.

OTERO, C. Alexandre Tansman: His life and works for the guitar. Amazon Digital Services LLC, 2011.

PEKACZ, J. Memory, history and meaning: Musical biography and its discontents. Journal of Musicological Research, v. 23, n. 1, p. 39-80, 2004.

RAE, C. Alexandre Tansman. In: Grove Music Online. Oxford University Press, 2001.

SOLOMOS, M. Néoclassicisme et Postmodernisme: Deux Antimodernismes. Musurgia, v. 5, n. 3/4, p. 91-107, 1998.

TANSMAN, A. Igor Stravinsky: the man and his music. New York: Putnam, 1949.

TANSMAN, A. Quelques Réflexions sur certains phénomènes équivoques de la musique contemporaine. In: HUGON, G.; TANSMAN-ZANUTTINI, M. Une voie lyrique dans un siècle bouleversé. Paris: L'Harmattan, 2005d. p. 61-68.

TANSMAN-ZANUTTINI, M.; HUGON, G. Une voie lyrique dans un siècle bouleversé. Paris: L'Harmattan, 2005.

TIMMONS, J.; FRÉMAUX, S. Alexandre Tansman: Diary of a 20th-Century Composer. Polish Music Journal, v. 1, n. 1, 1998.

WHEELDON, M. Anti-Debussyism and the Formation of French Neoclassicism. Journal of the American Musicological Society, v. 70, n. 2, p. 433-474, 2017.

WHITTALL, A. Neoclassicism. In: Grove Music Online. Oxford University Press, 2001.

WILEY, C. M. Re-writing composers' lives: critical historiography and musical biography. University of London, 2008. PhD.

WILEY, C. M. Biography and the New Musicology. (Auto)Biography as a Musicological Discourse, Belgrado, v. 3, p. 3-27, 2010. 
ZIGANTE, F. The Tansman-Segovia Collaboration. In: GILARDINO, A. Alexandre Tansman: Posthumous Works for Guitar. Ancona: Bèrben, 2003. p. 13-19.

\section{ABOUT THE AUTHOR}

Luigi Brandão is a classical guitarist and Master of Music by the Graduate Program in Music (PPGMUS) - UDESC. Since the beginning of his undergraduate course in classical guitar, he has been producing free concerts in public places, with music for classical guitar and other formations of concert music. His main research interests are (1) the guitar repertoire of the $20^{\text {th }}$ century, (2) musicology, theory, criticism, sociology and history of music, (3) education and (4) musical performance. ORCID: $\underline{\text { https://orcid.org/0000-0002-5300-1272. E-mail: luigibrandao@tutanota.com }}$ 